\title{
Evaluation (need, objectives and content dimensions) of Primary 5th -8th Grade Physical Education and Sport Curriculums
}

\author{
Gürbüz OCAK ${ }^{*}$ and Neriman ATASEVEN \\ Education Faculty, Afyon Kocatepe University, Afyon, Turkey
}

\begin{abstract}
Evaluation of the curriculum gives important information about success of the curriculum and it can be more effective with a redevelopment process. So, it is necessary that deficiencies that exist in physical education and sport curriculums should be reviewed and evaluated to maintain functionality of these curriculums which are important for students' multilateral development. Aim of this study is to evaluate need, objectives and content dimensions of 5th -8th physical education and sport curriculums. In accordance with this general aim, eligibility levels of the curriculum for "the needs and theoretical aspects", "objectives", "content" criteria were examined. Rubric for Curriculum Evaluation was used to evaluate the curriculums. Curriculums are examined independently by $3 \mathrm{PhD}$ students in accordance with the criteria in RCE. Criteria in RCE were rated by observers and an evaluation is made by using the average of the scores that 3 observers give for the same items. Furthermore, gap width of criteria rated between 1 and 5 is calculated. Study was designed in qualification research method and the case study was used as a model. According to research findings, it is seen that needs dimension of 5th, 6th, 7th and 8th grade physical education and sports curriculum is appropriate to the extent of the need in a moderate level; objectives of curriculum is appropriate to the extent of objectives and content dimension of curriculum is appropriate to the extent of content.
\end{abstract}

Key Words: Physical Education and sports, Curriculum, Physical Education and sport Curriculum

\section{Introduction}

In contemporary societies, it is focused on the need for individuals' physical development besides their cognitive development to raise them in many aspects as a whole (Aras, 2013). In this context, it can be said that physical education has an important place in general education. Because, physical education helps students' development of cognitive, emotional, social and psychological (Akdoğan, 2009) besides their development of physical and anatomical with formation of muscular, skeletal and diarthroses (Arac1, 2000).

\footnotetext{
* Corresponding author: gurbuzocak@gmail.com
} 
It is expected that Physical Education and Sport lesson is guiding and supporting students to improve their competence to act and to acquire active and healthy living habits (ME, 2013). With reference to this, it is aimed to help individuals' growth and development, make sport their parts of lives and make them comprehend cultural aspects of sport (ME, 2008). To realize these aims, it needs qualified teachers, efficient students, necessary equipment and effective curriculum.

Curriculum which is one of the cornerstones of education should be constantly developed to maintain its functionality. To do this, curriculum evaluation, "which is a process including data collection about effectiveness of curriculum, compare data obtained with curriculum criteria and interpret and decide about effectivity it" (Erden, 1998: 10) should be carried out. Evaluation of the curriculum gives important information about success of the curriculum and it can be more effective with a redevelopment process.

In this context, it is necessary that deficiencies that exist in physical education and sports curriculums should be reviewed and evaluated to maintain functionality of these curriculums which are important for students' multilateral development. Based on this requirement, Ministry of education made some regulations on physical education curriculums according to evaluation process. These curriculums were updated in 2005-2006 education period and implemented from 2006-2007 term. In 2013-2014 education period, these curriculums were abolished and Physical Education and Sport Curriculum were begun to use for $5^{\text {th }}-8^{\text {th }}$ classes (ME, 2013). Furthermore, there are many studies that evaluate physical education curriculum. In these studies, physical education curriculums in preschool (Altınkök, 2006), primary (Arslan, 2008) and secondary (Bilgin, 2007) are evaluated. In most of the studies, evaluation is done with teachers' view (Güllü, Güllü ve Güllü, 2009; Gülüm, 2009; Kalemoğlu, 2011) and stakeholders (Demirhan ve diğerleri, 2008) are used. Physical education curriculums are also evaluated according to realization level of objectives (Dalaman ve Korkmaz, 2010; Taşmektepligil, Yılmaz, İmamoğlu ve Kılcıgil, 2006). Although there are many studies for physical education curriculum, there is a few studies to evaluate physical education and sport curriculum (Aras, 2013; Havadar ve Taşdan, 2015). In these studies, it is indicated that curriculum should be evaluated and redeveloped; experts and practitioners should be included to the process and teachers should be informed about the curriculum. While examining these studies, it is seen that there is no study which evaluate the curriculums by investigating each components of curriculum inclusively. So, this study is expected to meet this requirement. Furthermore, this study helps curriculum developers in curriculum development process. Aim of this study is to evaluate 5th -8th physical education curriculums. In accordance with this general aim, it is sought answers for the following problem and sub-problems.

Problem: What are the levels of (need, objectives and content dimensions) 5th -8th Grade Physical Education and Sports Curriculums according to determined criteria?

Sub-problems:

- What is the eligibility levels of the 5th -8th Grade Physical Education and Sport Curriculum for "the needs and theoretical aspects" criteria?

- What is the eligibility levels of the 5th -8th Grade Physical Education and Sport Curriculum for "objectives" criteria?

- What is the eligibility levels of the 5th -8th Grade Physical Education and Sport Curriculum for "content" criteria? 


\section{Method}

\section{Research Design}

Study was designed in qualification research method and nested case study model that is the type of case study design was used. In nested case study model, each case included in the study is studied in itself by being divided into several sub-units (Yıldırım and Şimşek, 2013).

\section{Data Collection Tool}

In this research, Rubric for Curriculum Evaluation (RCE) (5: very convenient to the curriculum, 4: convenient to the curriculum, 3: convenient to the curriculum in moderate level, 2: convenient to the curriculum in low level, 1: inconvenient to the curriculum, 0 : no info) was used to evaluate the needs and theoretical aspects, objectives, content, learning situation and testing situation dimensions of curriculums. Primarily, literature is reviewed and criteria are determined for preparation of the scale. After that, these criteria are compared with the criteria of "Curriculum Evaluation Scale" (CES) (Ocak ve Akkaş, 2014; Ocak ve Gökteke, 2014; Ocak ve Yurtseven, 2015) and items that aren't in CES are added. Number of criteria of the scale examined independently by 1 expert and 3 doctoral student is 183 . Scale is composed of five categories: the needs and theoretical aspects, objectives, content, learning situation and testing situation. Experts graded the criteria in the scale according the curriculums with the score like 5: very convenient to the curriculum, 4: convenient to the curriculum, 3: convenient to the curriculum in moderate level, 2: convenient to the curriculum in low level, 1: inconvenient to the curriculum, 0: no info. Reliability of the data was calculated with reliability formula of Miles and Huberman (1994)

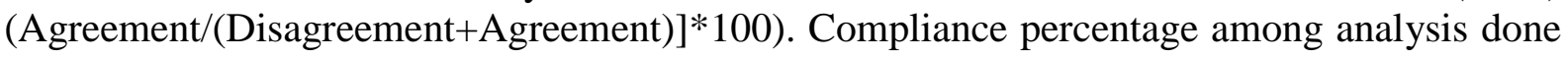
by two of observers is 0,86 .

Furthermore, gap width of criteria rated between 1 and 5 is calculated by gap width formula [(Gap width= (Sequence With)/(Number of Group)] and options and limit in the scale formed by this as following:

Table 1: Gap Width of the Scale

\begin{tabular}{lll}
\hline Very convenient to the curriculum (VCC) & 5.00 & 4.20 \\
\hline convenient to the curriculum (CC) & 4.19 & 3.40 \\
\hline convenient to the curriculum in moderate level (CCML) & 3.39 & 2.60 \\
\hline convenient to the curriculum in low level (CCLL) & 2.59 & 1.80 \\
\hline inconvenient to the curriculum (IC) & 1.79 & 1.00 \\
\hline No info (NI) & 0 & \\
\hline
\end{tabular}

\section{Process of Data Collection and Data Analysis}

5th -8th Grade Physical Education and Sport Curriculums (need, objectives and content dimensions) are examined independently by 3 doctoral students in accordance with the criteria in RCE. Criteria in RCE are regarded as criteria for curriculum evaluation and each criterion are graded by the observers. After that, an evaluation is made by using the average of the scores that 3 observers give for the same items. Document analysis was used as a way of data collection. Researchers can get the data s/he need without doing any observation and interview in document analysis technique which contains the analysis of the 
written materials consisted of information about a phenomenon aimed to investigated (Yıldırım and Şimşek, 2013). In this research, the documents investigated are 5th -8th Grade Physical Education and Sport Curriculum. Descriptive analysis was used to analyze data. The purpose of descriptive analysis is to make raw data understandable and usable for the readers. Data obtained as a result pf descriptive analysis are summarized and interpreted in accordance with a predetermined theme (Yıldırım and Şimşek, 2013).

\section{Findings} are given.

In this part, findings acquired by investigation of the curriculum according to criteria

What is the eligibility levels of the $5^{\text {th }}-8^{\text {th }}$ Grade Physical Education and Sports

Curriculum for "the needs and theoretical aspects" criteria?

In this research, an answer was sought to the question "What is the eligibility levels of the 5th -8 th Grade Physical Education and Sports Curriculum for "the needs and theoretical aspects" criteria?" for the first sub-problem. Evaluation result for "the needs and theoretical aspects" category is given in Table 2 :

Table 1: Eligibility levels of the $5^{\text {th }}-8^{\text {th }}$ Grade Physical Education and Sports Curriculum for "the needs and theoretical aspects" criteria

\begin{tabular}{|c|c|c|c|c|c|c|}
\hline & NEEDS AND THEORETICAL ASPECTS & $\begin{array}{l}- \\
\overline{0} \\
0 \\
0 \\
0\end{array}$ & $\begin{array}{l}N \\
\vdots \\
0 \\
0 \\
0 \\
0\end{array}$ & $\begin{array}{l}\infty \\
\vdots \\
0 \\
0 \\
0 \\
0 \\
0 \\
0\end{array}$ & $\mathbf{X}$ & 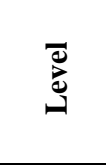 \\
\hline 1. & The vision of the curriculum is accessible. & 5 & 5 & 5 & 5 & VCC \\
\hline 2. & The curriculum is easy to understand & 5 & 5 & 5 & 5 & VCC \\
\hline 3. & $\begin{array}{l}\text { The curriculum has been prepared based on a single learning } \\
\text { theory. }\end{array}$ & 5 & 5 & 5 & 5 & VCC \\
\hline 4. & $\begin{array}{l}\text { Explanation in the curriculum is sufficient enough to guide } \\
\text { teacher. }\end{array}$ & 4 & 4 & 5 & 4,33 & VCC \\
\hline 5. & $\begin{array}{l}\text { Individual differences of students are taken into account in the } \\
\text { curriculum. }\end{array}$ & 5 & 5 & 5 & 5 & VCC \\
\hline 6. & $\begin{array}{l}\text { The curriculum has a capacity for integrating with other } \\
\text { lessons. }\end{array}$ & 5 & 5 & 5 & 5 & VCC \\
\hline \multicolumn{7}{|l|}{7.} \\
\hline & 7.1. Delphi technique & 0 & 0 & 0 & 0 & NI \\
\hline & Survey development technique & 0 & 0 & 0 & 0 & NI \\
\hline & Pro-gel (dacum) technique & 0 & 0 & 0 & 0 & $\mathrm{NI}$ \\
\hline & Job analysis technique & 0 & 0 & 0 & 0 & $\mathrm{NI}$ \\
\hline & Measurement tools - testing technique & 0 & 0 & 0 & 0 & NI \\
\hline & Interview-group meetings technique & 0 & 0 & 0 & 0 & $\mathrm{NI}$ \\
\hline & Observation techniques & 0 & 0 & 5 & 1,67 & $\mathrm{IC}$ \\
\hline & Literature review technique & 0 & 0 & 0 & 0 & $\mathrm{NI}$ \\
\hline \multicolumn{7}{|c|}{$\begin{array}{l}\text { 8. Level of using need analysis approaches in need analysis } \\
\text { process: }\end{array}$} \\
\hline & Differences approach & 0 & 0 & 0 & 0 & $\mathrm{NI}$ \\
\hline & Descriptive approach & 0 & 0 & 0 & 0 & NI \\
\hline & Democratic approach & 3 & 3 & 3 & 3 & CCML \\
\hline & Analytical approach & 3 & 3 & 3 & 3 & CCML \\
\hline & $\begin{array}{l}\text { Level of utilizing the resource of need while determining } \\
\text { needs }\end{array}$ & & & & & \\
\hline
\end{tabular}




\begin{tabular}{cllllll}
\hline 9.1. & Individual & 5 & 5 & 5 & 5 & VCC \\
\hline 9.2. & Society & 5 & 5 & 5 & 5 & VCC \\
\hline 9.3. & Subject Area & 5 & 5 & 5 & 5 & VCC \\
\hline 10. Level of utalising source of needs: & & & & & \\
\hline 10.1. & Experts' views & 5 & 5 & 5 & 5 & VCC \\
\hline 10.2. & Students' views & 5 & 5 & 5 & 5 & VCC \\
\hline 10.3. & Teachers' views & 5 & 5 & 5 & 5 & VCC \\
\hline 10.4. & Parents' views & 5 & 5 & 5 & 5 & VCC \\
\hline 10.5. & Managers' views & 5 & 5 & 5 & 5 & VCC \\
\hline 10.6. & Inspectors' views & 0 & 1 & 0 & 0,33 & IC \\
\hline 10.7. & NGOs' views & 0 & 0 & 0 & 0 & NI \\
\hline GENERAL MEAN & & & $\mathbf{4 . 3 0}$ & \multicolumn{2}{l}{ VCC } \\
\hline
\end{tabular}

As seen in Table 2, it is seen that needs and theoretical aspects dimension of $5^{\text {th }}-8^{\text {th }}$ grade physical education curriculum is convenient to the extent of the need and theoretical aspects in a moderate level $(X=2.76)$. When the criterion about theoretical aspect is examined, it is seen that vision of the curriculum is accessible $(X=5.00)$, it is easy to understand $(\mathrm{X}=5.00)$, it has been prepared based on a single learning theory $(X=5.00)$, explanation in it is sufficient enough to guide teacher $(X=4.33)$, individual differences of students are taken into account in it $(X=5.00)$ and it has a capacity for integrating with other lessons $(X=5.00)$. When the criterion about determining needs is examined, it is seen that individual $(X=5.00)$, society $(X=5.00)$ and subject area $(X=5.00)$ sources are utilized. Observation technique from need analysis techniques is used in a limited extent $(X=1.67)$; but other techniques aren't used. In need analysis, views of experts $(X=5.00)$, students $(X=5.00)$, teachers $(X=5.00)$, parents $(X=5.00)$, managers $(X=5.00)$, inspectors $(X=5.00)$, NGOs $(X=5.00)$. In need analysis process, democratic $(\mathrm{X}=3.00)$ and analytic $(\mathrm{X}=3.00)$ approaches from need analysis approaches are relatively used, but differences $(X=0.00)$ and descriptive $(X=0.00)$ approaches aren't used.

What is the eligibility levels of the $5^{\text {th }}-8^{\text {th }}$ Grade Physical Education Curriculum for "objectives" criteria?

In this research, an answer was sought to the question "What is the eligibility level of the $5^{\text {th }}-8^{\text {th }}$ Grade Physical Education Curriculum for "objectives" criteria?" for the second sub-problem. Evaluation result for "objectives" category is given in Table 3:

Table 2: Eligibility levels of the $5^{\text {th }}-8^{\text {th }}$ Grade Physical Education Curriculum for "objectives" criteria






\begin{tabular}{|c|c|c|c|c|c|c|c|}
\hline & 2.3. & Progressivism & 5 & 5 & 5 & 5 & VCC \\
\hline & 2.4 & Reconstructivizm & 4 & 4 & 4 & 4 & $\mathrm{CC}$ \\
\hline \multirow[t]{4}{*}{3.} & Neec & npensation level of gains: & & & & & \\
\hline & 3.1. & Individual & 5 & 5 & 5 & 5 & VCC \\
\hline & 3.2 & Society & 5 & 5 & 5 & 5 & VCC \\
\hline & 3.3. & Subject area & 5 & 5 & 5 & 5 & VCC \\
\hline 4. & \multicolumn{2}{|c|}{ Gains are clear and comprehensible } & 5 & 5 & 5 & 5 & VCC \\
\hline 5. & \multicolumn{2}{|c|}{ Gains are feasible } & 5 & 5 & 5 & 5 & VCC \\
\hline 6. & \multicolumn{2}{|c|}{$\begin{array}{l}\text { Gains are sorted into from easy to difficult and from simple to } \\
\text { complex. }\end{array}$} & 5 & 5 & 5 & 5 & VCC \\
\hline 7. & \multicolumn{2}{|c|}{ Gains are consistent. } & 5 & 5 & 5 & 5 & VCC \\
\hline 8. & \multicolumn{2}{|c|}{ Gains are measurable. } & 5 & 5 & 5 & 5 & VCC \\
\hline 9. & \multicolumn{2}{|c|}{ Gains are complementary to each other. } & 5 & 5 & 5 & 5 & VCC \\
\hline 10. & \multicolumn{2}{|c|}{ Gains are process-driven } & 5 & 5 & 5 & 5 & VCC \\
\hline 11. & \multicolumn{2}{|c|}{ Gains are accessible in terms of time. } & 4 & 3 & 5 & 4 & CC \\
\hline 12. & \multicolumn{2}{|c|}{ Gains are accessible in terms of lessons period. } & 4 & 3 & 5 & 4 & $\mathrm{CC}$ \\
\hline 13. & \multicolumn{2}{|c|}{$\begin{array}{l}\text { Gains are correlated with the gains of other lessons (consistency } \\
\text { principle). }\end{array}$} & 5 & 5 & 5 & 5 & VCC \\
\hline 14. & \multicolumn{2}{|c|}{ Gains are correlated with other gains of the same lesson. } & 5 & 5 & 5 & 5 & VCC \\
\hline 15. & \multicolumn{7}{|c|}{ Eligibility level of gains to basic skills: } \\
\hline & 15.1 & Critical thinking & 5 & 5 & 5 & 5 & VCC \\
\hline & 15.2 & Creative thinking & 5 & 5 & 5 & 5 & VCC \\
\hline & 15.3 & Communication skills & 5 & 5 & 5 & 5 & VCC \\
\hline & 15.4 & Research and questioning skills & 5 & 5 & 5 & 5 & VCC \\
\hline & 15.5 & Problem solving skills & 5 & 5 & 5 & 5 & VCC \\
\hline & 15.6 & Skills to use information technologies & 5 & 5 & 5 & 5 & VCC \\
\hline & 15.7 & Entrepreneurship skills & 5 & 5 & 5 & 5 & VCC \\
\hline & 15.8 & Skills to use Turkish accurately and effectively & 5 & 5 & 5 & 5 & VCC \\
\hline 16. & Bloo & taxonomy is taken into account while determining gains & 0 & 0 & 0 & 0 & $\mathrm{NI}$ \\
\hline 17. & $\begin{array}{l}\text { Bloo } \\
\text { gains }\end{array}$ & revised taxonomy is taken into account while determining & 0 & 0 & 0 & 0 & $\mathrm{NI}$ \\
\hline 18. & $\begin{array}{l}\text { Whil } \\
\text { acco }\end{array}$ & termining gains, individual differences are taken into & 5 & 5 & 5 & 5 & VCC \\
\hline
\end{tabular}

19. Level of gains for developing students' developmental dimension.

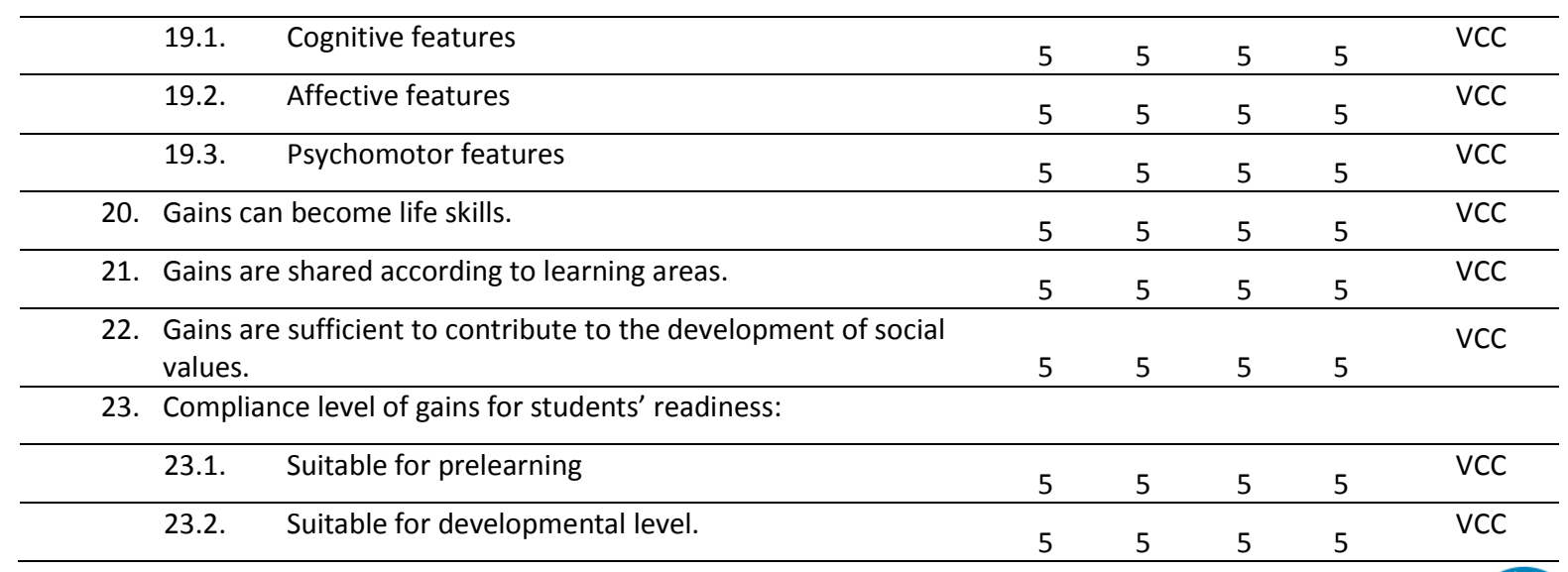




\begin{tabular}{rlrrrrr}
\hline 23.3. & Suitable for interests. & 5 & 5 & 5 & 5 & VCC \\
\hline 23.4. & Suitable for individual features. & 5 & 5 & 5 & 5 & VCC \\
\hline GENERAL MEAN & & & \multicolumn{2}{c}{$\mathbf{4 . 5 0}$} & & \multirow{2}{*}{ VCC } \\
\hline
\end{tabular}

As it seen in Table 3, objectives of physical curriculum are appropriate to the extent of objectives in a high level $(X=4.50)$. Gains of curriculum are clear, comprehensible $(X=5.00)$ and feasible $(X=5.00)$. Gains are sorted into from easy to difficult and from simple to complex $(X=5.00)$ and they are consistent $(X=5.00)$. Gains are measurable $(X=5.00)$ and process-driven $(X=5.00)$. Gains are relatively accessible in terms of time $(X=4.00)$. Gains are correlated with the gains of other lessons $(X=5.00)$ and other gains of the same lesson $(X=5.00)$. While determining gains, individual differences are taken into account $(X=5.00)$. Gains are determined with the ability to become life skills $(X=5.00)$. It is seen that gains are convenient to distant, general and specific objectives. Gains are shared according to learning areas $(X=5.00)$. Gains are sufficient to contribute to the development of social values $(X=5.00)$. Overlaping level of gains with Progressivism $(X=5.00)$ and Reconstructivizm $(X=5.00)$ is high, but it is low with Perennialism $(X=1.00)$ and Essentialism $(X=1.00)$. Need conpensation level of gains for individual $(X=5.00)$, society $(X=5.00)$ and subject area $(X=5.00)$ is very high. Bloom's taxonomy $(X=0.00)$ and Bloom's revised taxonomy $(X=0.00)$ aren't taken into account while determining gains. Eligibility level of gains to basic skills is high $(X=5.00)$. Cognitive, affective and psychomotor features of students are taken into account while determining gains. Furthermore, compliance level of gains for students' prelearning $(X=5.00)$, developmental level $(X=5.00)$, interests $(X=5.00)$ and individual features $(\mathrm{X}=5.00)$ is high.

What is the eligibility levels of the $5^{\text {th }}-8^{\text {th }}$ Grade Physical Education and Sports

Curriculum for "content" criteria?

In this research, an answer was sought to the question "What is the eligibility levels of the $5^{\text {th }}-8^{\text {th }}$ Grade Physical Education and Sports Curriculum for "content" criteria?" for the first sub-problem. Evaluation result for "content" category is given in Table 4:

Table 3: Eligibility levels of the $5^{\text {th }}-8^{\text {th }}$ Grade Physical Education and Sports Curriculum for "content" criteria

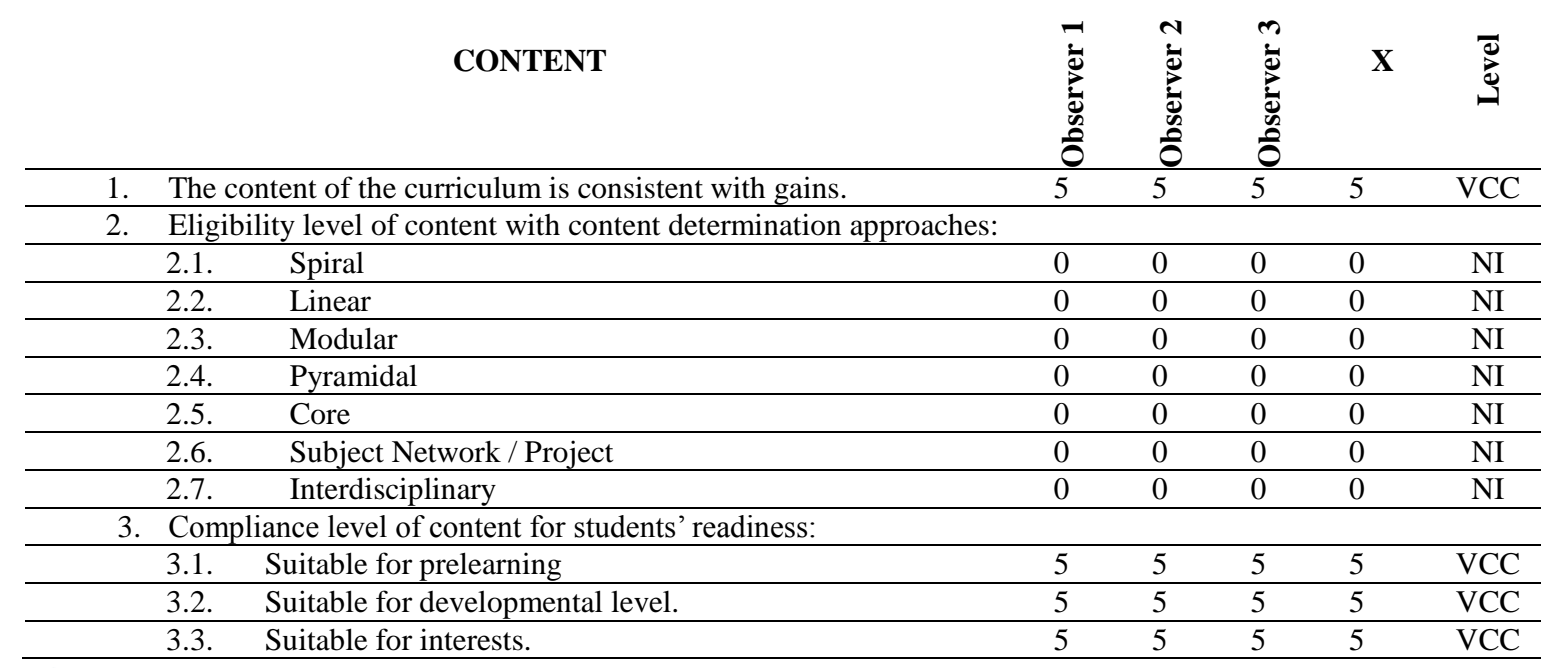




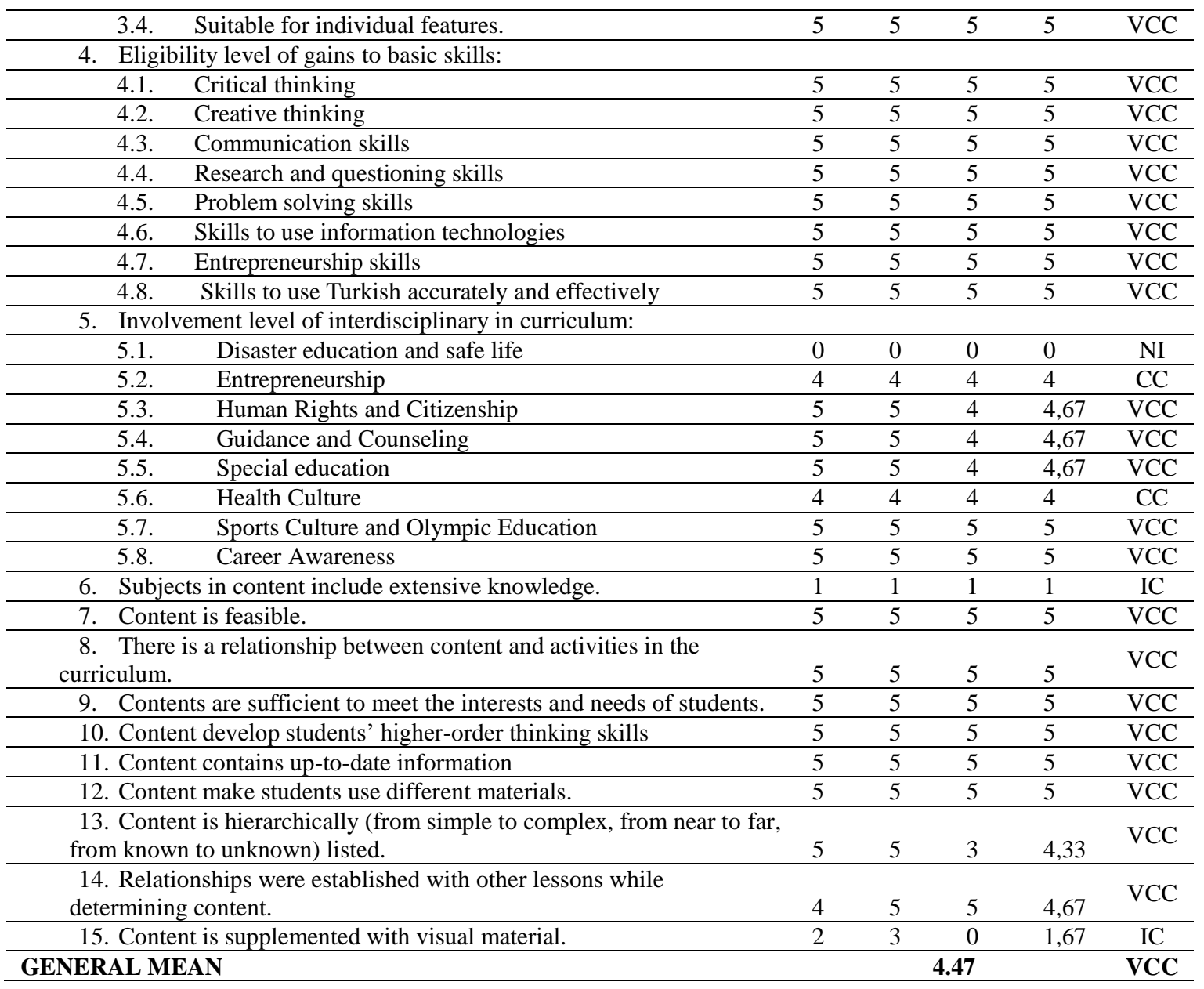

As it seen in Table 4, content dimension of curriculum is appropriate to the extent of content $(X=4.47)$ in high level. It is also seen that content of the curriculum is consistent with gains $(X=5.00)$. While content is determining, none of the content determination approaches are utilized $(X=0.00)$. Compliance level of content for students' prelearning $(X=5.00)$, developmental level $(X=5.00)$, interests $(X=5.00)$, individual features $(X=5.00)$ is high. Compliance level of content to basic skills is high $(X=5.00)$. Human Rights and Citizenship $(X=4.67)$, Guidance and Counseling $(X=4.67)$, Special education $(X=4.67)$, Sports Culture and Olympic Education $(X=5.00)$ and Career Awareness $(X=5.00)$ interdisciplinary play a part in the curriculum in a high level; Entrepreneurship $(X=4.00)$ and Health Culture $(\mathrm{X}=4.00)$ interdisciplinary play a part in a relatively high level; but Disaster education and safe life $(X=0.00)$ interdisciplinary doesn't play a part in curriculum. Subjects in content don't include extensive knowledge $(\mathrm{X}=1.00)$. Content is feasible and there is a relationship between content and activities in the curriculum $(X=5.00)$. Contents are sufficient to meet the interests and needs of students $(X=5.00)$. Content containing up-to-date information $(X=5.00)$ develop students' higher-order thinking skills $(X=5.00)$. Content make students use different materials $(X=5.00)$. Content is hierarchically listed $(X=4.33)$ and relationships are established with other lessons while determining it $(\mathrm{X}=4.67)$. Lastly, it is seen that content isn't supplemented with visual material $(\mathrm{X}=1.67)$.

\section{Conclusion, Discussion and Implications}

In this study in which needs, objectives and content dimensions of 5th -8th physical education and sports curriculums are evaluated, Rubric for Curriculum Evaluation (RCE) was 
used to evaluate the curriculums. Curriculums are examined independently by 3 doctoral students in accordance with the criteria in RCE. Criteria in RCE were rated by observers and an evaluation is made by using the average of the scores that 3 observers give for the same items. Furthermore, gap width of criteria rated between 1 and 5 is calculated.

According to result of the evaluation, it is seen that needs and theoretical aspects dimension of $5^{\text {th }}-8^{\text {th }}$ grade physical education curriculum is convenient to the extent of the need and theoretical aspects in a high level. According to this finding, it can be said that determination of needs seen as the most important component of the curriculum (Demirel, 2012; Ertürk, 2013) is realized at desired level. Needs analysis process is a guide for analyzing and determining needs of individual, culture and society and determining objectives, content and learning activities (Taba, 1962). All other components of the curriculum are determined after this analysis. Thus, an unhealthy curriculum occurs in need analysis process functioning in an unhealthy manner. Research findings indicate that views of stakeholders are used in need determination process. However, views of inspector making supervision in schools and CSO working in the field of education aren't utilized. In physical education and sport curriculum, it is stated that "Curriculum was planned in liaison with individual (e.g. students, teachers, parent and administrators) and institutional (school, Provincial Sports Directorate, Sports federations, municipalities, Provincial Health Directorate) stakeholders." (ME, 2013:20). While determining needs, it is seen that individual, society and subject area sources are taken into account. In this perspective, the program is said to tend to meet needs. Furthermore, there is very little information about needs assessment phase, which resources are used and how and how much they are utilized. In this point, more information should be given in the curriculum. It can be said that although not included in the curriculum, presenting booklets consisting needs determination studies and R \& D activities made by Ministry of Education at regular intervals can be useful on behalf of informing educators.

It is also found in this study that objectives are appropriate to the extent of objectives in a high level. Based on this result, it can be said that objectives of physical education curriculum is appropriate to objective criteria of an efficient curriculum. Because objectives are base for developing and evaluating the curriculums (Varış, 1988), this finding is important for physical education curriculum to be more efficient. Furthermore, it is very important for students that the gains of curriculums are determined according to their developmental level, interests and needs. It is stated in curriculum that physical education and sport curriculum for students in grade 5-8 was designed according to students' developmental needs and their educational priorities." (ME, 2013:10). In this way, it can be said that possibility of the curriculum to be completed with success will be high. Because, when it is thought that gains are statements about what students know, understand and do at the end of learning period (Çelik, 2006), it is a positive result that gains are determined according students. Another finding about curriculum gains is that gains of curriculum are clear, comprehensible and feasible. This is important for teachers to understand and apply gains in their class. This result of this research is similar to some of the research findings. In some research evaluating physical education curriculum, it is indicated that statements in curriculum gains are clear, understandable, consistent (Bulut, 2006; Gündoğar, 2006; Özdemir, 2006) and feasible (Erdoğdu ve Öçalan, 2009). Another result for objectives is that gains are correlated with the gains of other lessons and other gains of the same lesson. Some examples such as "Student explains states that affect her/his or other students" health and security" or "Students know the health problems during physical activities and the way to protect themselves from these problems" can be given for correlation with other lessons (ME, 2013: 26). It can be said that this feature of gains give an opportunity for students to apply the gain into different settings and in this way this gain can 
be permanent. Furthermore, it is found that gains are sufficient to contribute to the development of social values. Some of the gains such as "Students gives value to share their tools, equipment and space in physical activity" and "Students understand the importance of activities and ceremonies made with class and school in national holidays" (ME, 2013: 30-31) can be example for this. It is also seen in the study that gains are in line with philosophy of progressivism and re-constructionism more. One of the gains such as "Students exhibit behaviors based on collaboration in games and activities." (ME, 2013: 30) can give as an example for the gains in line with progressivism. Working in collaboration is an important factor in progressivist curriculum (Sönmez, 2009). Furthermore gains are said to develop basic skills. For example, some example such as "Students use different ways of communication in games and activities" (communication skills) and "Students find and present original dance choreography” (creative thinking) can be given (ME, 2013:33).

It is seen in the study that content dimension of curriculum is appropriate to the extent of content in high level. It is also in a harmony with objectives of the curriculums. It can be said that it is a positive result; because content should be determined limited according to objectives (Sönmez, 2010). Contents are sufficient to meet the interests and needs of students and to develop their developmental level. It is important for students to adapt to the curriculum. It is seen that content of the curriculum develop basic skills and contains interdisciplinary. It is stated in curriculum that "Curriculum contains some basic skills such as critical thinking, creative thinking, communication skills etc." (ME, 2013: 6-7). Also, it is indicated in curriculum that "It is very important to relate the physical education and sport lesson with other lesson; so teachers of physical education and sport lesson work in liaison with teachers with other lessons." (ME, 2013: 20). However, Disaster education and safe life interdisciplinary isn't seen in curriculum content. When as, physical education lessons are expected to be related with disasters, ways of preventing disasters and training of human behavior during disasters. Lastly, Content containing up-to-date information isn't supplemented with visual material. It is an expected result for physical education and sports curriculum.

\section{REFERENCES}

Akdogan, C. (2009). The Views of Physical Education Teachers on the New Education Program of the Physical Education Classes in Primary Education. Master Thesis. Gazi University Institute of Educational Sciences, Ankara.

Aras, O. (2013). Investigation of View and Attitudes of Physical Education Teachers Working and Students Studying at the Second Level of Public Schools about Physical Education Lesson. Master Thesis. Gazi University, Institute of Educational Sciences, Ankara.

Arslan, Y. (2008). Classroom Teachers' Views on Elementary School Physical Education

Curriculum and Physical Education Course. Master Thesis, Hacettepe University, Institute of Health Sciences, Ankara.

Araci, H. (2000). Physical Education for Teachers and Students in School [Öğretmenler ve Öğrenciler İçin Okullarda Beden Eğitimi]. Ankara: Nobel.

Altınkok, M. (2006). Investigation of Effect of Special Physical Curriculum Including Basic 
Motor Movements on Development of Basic Motor Movements of Children at the Age of 5-6. Master Thesis, Marmara University, Institute of Educational Sciences, Istanbul.

Bilgin, S. (2009). The Evaluation of Teachers' View about Physical Education Curriculum for High School Level (Class 9, 10 and 11). Master Thesis, Marmara University, Institute of Educational Sciences, Istanbul.

Bulut, I. (2006). Evaluation of Effectiveness of New Primary School Curriculums in Practice. [Yeni İlköğretim Birinci Kademe Programlarının Uygulamadaki Etkinliğinin Değerlendirilmesi]. Doctorate Dissertation. Firat University Institute of Social Sciences, Elazig.

Celik, F. (2006). New Trends on Goals and Setting Goals in the Turkish Education System [Türk Eğitim Sisteminde Hedefler Ve Hedef Belirlemede Yeni Yönelimler), Journal Of Burdur Education Faculty, 11, 1-15.

Dalaman, O. \& Korkmaz, I. (2010). The perception of elementary and physical education teachers about acquiring objectives of physical education. Nigde University Journal of Physical Education and Sport Sciences, 4(3), 172-185.

Demirel, O.(2010). Curriculum Development From Theory to Practice [Kuramdan Uygulamaya Program Geliştirme]. Ankara:Pegem Academy.

Erden, M. (1998). Curriculum Development in Education [Eğitimde Program Geliştirme]. Ankara: Anı Publishing

Erdogdu, M. \& Ocalan, M. (2010). The opinions of physical education teachers on evaluating the second level primary school physical education lesson program. SPORMETREJournal of Physical Education and Sport Sciences, 8(4), 151-162.

Erturk, S. (2013). Curriculum Development in Education [Eğitimde Program Geliştirme]. Ankara: Cihan Press

Gullu, M., Gullu, E. \& Gullu, A. (2009). Investigated views of school physical education teachers working at primary schools related to constructivist approach . Kafkas University Journal of the Institute of Social Sciences, 1(3), 207-219.

Gulum, V. (2008). The Eavaluation of Physical Education Teachers About the Physical Education Curriculum at Primary Schools In Adana. Master Thesis, Cukurova University, Institute of Health Sciences, Adana.

Gundogar, A. (2006). Implementation Status of Primary School Curriculum Changed in 2005-2006 School Period [Yılında Değişen İlköğretim Programının Uygulanma Durumu (Adlyaman Ili Örneği]. Master Thesis, Firat University Institute of Social Sciences, Elazig. 
Havadar, T. \& Tasdan, M. (2015). The views of physical education curriculum in the $4^{\text {th }}$ and $5^{\text {th }}$ Grades of Primary School. Inönü University Journal of Physical Education and Sport, 2(1), 29-46.

Kalemoglu, Y. (2011). Türkiye ve İngiltere'deki İlköğretim Beden Ĕ̆itimi Dersi Öğretim Programlarının Öğretmen Görüşlerine Göre Karşılaştırmalı Olarak Incelenmesi. Doctorate Dissertations, Gazi University, Institute of Educatioal Sciences, Ankara.

ME. (2005). Physical Education Curriculum (Grades 1st- $8^{\text {th }}$ ) [Beden Eğitimi Dersi (1.-8.

Sinıf) Öğretim Programı]. Retrieved from

http://ttkb.meb.gov.tr/program2.aspx?islem=1\&kno=19 in 15. 03. 2015

ME. (2013). Physical Education and Sport Curriculum [Beden Eğitimi ve Spor Dersi (5., 6., 7. ve 8. Sınıf) Öğretim Programı]. Retrieved from http://ttkb.meb.gov.tr/www/ogretim-programlari/icerik/72 in 15. 03. 2015.

Miles, M. B. \& Huberman, A. M. (1994). An Expanded Sourcebook Qualitative Data Analysis. United States of America: Sage Publications.

Ocak, İ. \& Akkaş-Baysal, E. (2014). Evaluation of $4^{\text {th }}$ grade science curriculum. $3^{\text {rd }}$ International Conference on Interdisciplinary Research in Education, Milano.

Ocak, G. ve Gökteke, Z. (2014). Evaluation of $5^{\text {th }}$ grade social science curriculum. $3^{\text {rd }}$ International Conference on Interdisciplinary Research in Education, Milano.

Ocak, G. ve Yurtseven, R. (2015). Evaluation of $5^{\text {th }}$ grade mathematic curriculum. $4^{\text {th }}$ International Congress of Educational Research, Sakarya.

Ozdemir, H. (2006). Teachers' View about Problems Encountered in Primary School $4^{\text {th }}$ and $5^{\text {th }}$ Grade Science Curriculum and Solutions for These Problems [İlkögretim Okullarl 4. ve 5. Sınıf Fen Bilgisi Ö̆gretim Programlarında Karşılaşılan Sorunlar ve Çözüm Önerilerine İlişkin Öğretmen Görüşleri (Konya İli Örneği)]. Master Thesis, Selcuk University Institute of Social Sciences. Konya.

Sonmez, V. (2009). Educational Philosophy [Eğitim Felsefesi]. Ankara: Anı Publishing

Sonmez, V. (2010). Handbook on Curriculum Development for Teachers [Program Geliştirmede Öğretmen El Kitabı]. Ankara: Pegem Akademi

Taba, H. (1962). Curriculum Development. New York: Harcourt, Brace\& World Inc.

Tasmektepligil, Y., Yilmaz, C., Imamoglu, O. \& Kilcigil, E. (2006). Realization level of physical education lesson's purposes in primary schools. SPORMETRE-Journal of Physical Education and Sport Sciences, 4(4), 139-147

Varıs, F. (1988). Curriculum Development in Education [Eğitimde Program Geliştirme]. Ankara: Ankara University Faculty of Education Publishing.

Tekin, H.(1996). Assessment and Evaluation in Education [Ĕgitimde Ölçme ve Değerlendirme]. Ankara: Yarg1 Publishing. 
Yalcin, H. (2009). Teachers' View about New Physical Education Curriculum Implemented in Public and Private Schools [Resmi ve Özel İlköğretim Okullarında Uygulanan Yeni Illkögretim Beden Ĕ̈itimi Öğretim Programına İlişkin Öğretmen Görüşleri (Ankara İli Örneği)]. Master Thesis. Ankara University Institute of Health Sciences, Ankara.

Yıldırım, A. \& Simsek, H. (2013). Qualitative Research Methods in Social Sciences [Sosyal Bilimlerde Nitel Araştırma Yöntemleri]. Ankara: Seçkin Publishing. 